\title{
May, Should, or Do, Administrative Judges Participate in the Management of the Public Sphere in the Rule of Law?
}

\author{
Adam Szot ${ }^{1}$ iD \\ Published online: 19 October 2019 \\ (c) The Author(s) 2019
}

\begin{abstract}
The article concerns the actual impact of courts controlling the activity of public administration on the direction of its activities and the content of issued decisions. In particular, it concerns sovereign individual decisions that affect the sphere of civil rights and freedoms. The aim of the article is to seek an answer to the question of whether independent judges actually participate in the process of management in the public sphere, which is characterised by elements of politics and (regardless of the answer to this question) whether such participation is allowed or (even) necessary in modern rule of law states. The main argument is that regardless of whether the courts controlling the administration have reformatory or exclusive cassation powers, they influence the decision-making process in the public sphere. At the same time, such influence not only does not violate the fundamental values of the rule of law, but is even sometimes necessary. This does not mean that courts should interfere in the management processes in the public sphere in every case.
\end{abstract}

Keywords Balancing of powers · Public sphere - Administrative discretion

\section{Introduction}

In the contemporary multi-centric, globalised world, boundaries become fuzzy and existing concepts are being re-defined. In that context, it is difficult to guard the classic Montesquieu's principle of the division and balance of powers. Additionally, one can ask a range of questions about "places" in which boundaries between individual powers in a state under the rule of law can become fuzzy and

\footnotetext{
This publication is a result of the research Project No. 2013/11/N/HS5/04212 entitled "The influence of judicial decisions on the discretionary power of public administration in the law application processes" funded by the National Science Centre (Poland).
}

Adam Szot

adam.szot@poczta.umcs.lublin.pl

1 Maria Curie-Sklodowska University, Pl. M. Curie-Sklodowskiej 5, 20-031 Lublin, Poland 
to what degree it is possible. The purpose of this publication is to look for answers to the following questions: (1) whether independent judges actually participate in the administration process in the public sphere ("DO") and also (2) whether such a participation is permitted ("MAY") or even necessary ("SHOULD") in a state, under the rule of law. I understand the participation in the management as each possibility to influence (impact) the decisions being made. Such participation is expressed in the influence that rulings of courts controlling the administration have on decisions issued by the administration (micro-management processes). As a result of their consistent making, individual public decisions having specific contents can transform into decision-making lines that create and also constitute a component of the administration policy in the public sphere (macro-management processes). I will look for an answer to the first question in the actual (i.e. not only legal) impact of court rulings on decisions made by the administration and an answer to the second question will be sought in the conceptual sphere by comparing arguments for and against the admission of the interference of courts with the public management with fundamental values of the state under the rule of law.

My main argument is that administrative judges in fact DO and at the same time they MAY and sometimes SHOULD participate in the public management in a rule of law state. My first argument is that, irrespectively of whether they have substantive or exclusive cassation powers, courts controlling the administration influence the decision-making process in the public sphere. My second argument is that such influence not only does not violate basic values of the rule-of-law state but is even desirable so that courts should have an opportunity ("MAY") but should not always actually ("SHOULD") interfere with management processes in the public sphere.

In the European tradition [14: 143-149], it is possible to distinguish two principal models of judicial control over the administration, i.e. the cassation model (negative control model) involving the elimination from the legal sphere of a defective decision made by public authorities and a substantive model (positive control model) entailing the possibility of a substantive adjudication by the court and the "replacement" of decisions issued by the administration with a court ruling. These are not separate models as legal systems of many states combine their components, however, with a marked prevalence of one of them. Additionally, the "depth" with which courts can go into administrative matters, especially in the case of the substantive adjudication, remains irrelevant from the perspective of deliberations included in this publication. Such considerations were given much space both in dogmas of the law and in the theory of the law. From that perspective, e.g. works by Wilberg and Elliott [22] and Grant [4: 507-536] or, within the civil law culture, by Kmieciak, e.g. [11: 149-150], deserve particular attention. So far, the majority of discussions regarding these matters have concentrated, in particular, on the possibility of judicial interference with the contents of a specific decision and the justification of such interference. Such an approach to the topic makes one fail to notice a wider perspective, namely the actual (not only legal) influence of courts on the modelling of administrative decisions in various cases other than the one analysed by the court. It also makes it impossible to notice the systemic, more complex influence of the court not only on an individual decision but also on a series of decisions, which influences 
the modelling of specific administrative customs related to the settlement of specific cases in a specific manner.

Considerations included in this work result from the research done as a part of a project relating to the influence of court rulings on public administration agencies, which subjected the jurisprudence of Polish administrative courts to the analysis (more than 1500 rulings). Comparative analyses relating to the influence of courts on public administration agencies in various European countries were also conducted [18]. The results of these analyses, combined with an analysis of the literature, and an analytical approach are the bases for the formulation of theses contained in this publication. The decision-making approach to law application processes is the starting point for these considerations.

For the sake of clarity, we should indicate at the beginning that, when writing about "an administrative court", we understand this term as a court that controls the administration, irrespectively of its placement in the judiciary in a state, i.e. it is a functional rather than a structural concept. It is of no importance to me whether such control is exercised as a part of a section separated from the common courts or in common courts. At the same time, only courts and the possibility of their influence on decisions made by the administration are of interest, along with all other entities that control the administration and can be assigned quasi-judicial features, e.g. administrative tribunals in Great Britain. ${ }^{1}$

\section{DO?}

The question whether administrative judges actually participate in management processes has to be answered affirmatively. A look at the actual processes taking place in the public administration and the judiciary from the decision-making point of view [12: 156-181]. makes it possible to gain a completely different perspective than in the case of a strictly juridical point of view. If we assume that the participation in the management process in the public sphere, being the sphere of executive agencies, can be understood as each opportunity to influence the contents of decisions made in that sphere, that phenomenon will be common in the case of the judicial control over the administration. A court verifying decisions made by public agencies influence - in a varied manner and with varied powerthe direction of actions taken and the contents of issued decisions. Additionally, such influence is independent on whether the court has reformatory competencies and can substantively decide in an administrative case or only cassation competencies and can only annul a defective decision. In both situations, its rulings become components of the sensu largo legal order and, as such, become a source of the law (from the decision-making perspective), also beyond the common law culture. Therefore, they constitute a material component of the validation and interpretation reasoning pursued by administrative agencies irrespectively of

\footnotetext{
${ }^{1}$ See disputes in the Anglo-Saxon doctrine regarding the systemic position of administrative tribunals [5: 486-527, 7].
} 
whether they are included in the formal catalogue of sources of the law recognised by the legislature. Of course, it does not mean that one can rely only on such a ruling (or a few rulings) and issue a decision neglecting other sources of the law, in particular (in the civil law culture) legal regulations or, especially, issue a decision not in line with standards contained in these sources.

When analysing the influence of rulings on decisions issued by public administration agencies, one can mention a few types of such influence [18: 65-79]. The first type that can be distinguished is the direct influence that covers all situations in which a court influences a specific administration agency in a specific law application process with the content of its ruling (its decision-making layer and/or argumentation layer). In these situations, an administrative case is referred back to the agency for re-examination. These cases include the annulment (cassation) of an administrative decision by the court with no replacement of that decision with a substantive ruling (if the administrative court is competent to do so). A substantive ruling will replace the administrative decision in a specific case so there is no influence on its content here. However, such a ruling will indirectly influence the issue of future decisions in other cases regarding corresponding facts. In principle, direct influence involves the agency being officially bound with factual and/or legal settlements or assessments of the court contained in the statements of reasons for a ruling. Additionally, the "power" of influence of a ruling depends on detailed procedural standards in force in a legal system. Another type of influence that can be distinguished is an indirect influence covering all other cases. It applies to situations in which an agency refers to the contents of a ruling related to a case different than the one examined by the administrative court. These will mainly include cases issued with regards to similar facts and a corresponding legal approach adopted by the same agency. In such cases, the administrative decision-maker has the most extensive knowledge of arguments expressed by the court that will perhaps examine a complaint against the projected decision in the future. With knowledge of earlier settlements made by the court in similar cases, the agency will (intentionally or not) reach for evaluations and arguments formulated in the court decision. In the light of the direct access to materials of the case and, therefore, to knowledge of findings made by the court as regards specific facts of the case, the agency examining "similar" cases in the future will take prior rulings into account. When distinguishing this type of influence, it is irrelevant whether a ruling referred to by an administration agency was a cassation or settled a case different in its essence (substantive ruling).

Direct and indirect influence can also be analysed from the perspective of being legally bound with the court ruling. Then, one can notice the legal and factual influence of rulings on decisions made in the public management sphere. The former covers all those cases in which an agency is legally obliged to reach for or (to use a stronger word) to adopt findings, evaluations and arguments expressed in a court ruling. Therefore, one can say with some simplification that all these cases are examples of formal influence described above. An actual influence occurs in each case of an agency reaching for court decisions and using them even to a minimum degree from the decision-making or argumentation perspective with regard to the entire process, its individual stages or, more extensively, to the decision-making policy. 
An administration agency is bound with the ruling (formal influence) and findings (actual or legal) made by the court in each case when the obligation to reach for or consider arguments expressed there results from the contents of legal standards in force. All other cases of a "voluntary" (understood as the lack of legal binding) reaching for prior court rulings are expressions of an indirect influence of the court on an agency. Obviously, the lack of a formal obligation means that a public administration agency can make findings different than those contained in the court ruling. However, in principle, it will consider at the stage of the search for a source of the normative basis for a future administrative decision to what degree the prior court ruling remains current in the analysed administrative case and to what degree it would be justified to use the findings and arguments expressed in it. There are varied arguments in favour of such an activity, including pragmatic ones, as by respecting assessments and arguments expressed in prior court decisions or rulings, especially in similar cases, an administration agency avoids the potential for its actions to be undermined, and axiological ones: relating both to the axiology of the entity applying the law, i.e. the agency's aim to retain the coherence within a legal order and the axiology of the legal system.

It is also worth noting that court rulings can influence both a single administrative case and the development of specific decision lines or administrative decision-making policies. As regards individual decision-making processes, the court influence (indirect) will be visible with regard to individual phases/stages of the law application process. Noticing it makes it possible to adopt an interesting perspective in the analysis according to which one can observe how court rulings influence individual lines of reasoning of an administering entity with regard to factual and legal findings and their qualification as well as the modelling of contents of an administrative decision, especially if an agency enjoys freedom of decision allowing it to determine the direction and/or scale of the settlement (in those cases where an agency enjoys freedom of choice). In turn, the analysis of the case law influence on decision-making processes from a wider perspective makes it possible to capture dependencies between the case law (especially the established and stable ruling practice) and development of the administration policy understood as an established conduct in specific cases or a widely understood protection of human rights and freedoms. Such influence can be observed both with regard to decision processes within a single administering entity and various agencies functioning in a system of task-based or hierarchical relationships.

The frequency with which public administration agencies reach for and use court rulings depends on many factors, including the contents of standards (especially procedural ones) in force in a legal system, the agency's knowledge of issued iudicatas, the attitude of the administration to the judiciary and the scope of discretionary power of administering entities. However, one has to remember that, in addition to cases of administrative court rulings being legally binding, public administration agencies can take advantage of the rulings but they are not obliged to do so. 


\section{MAY or SHOULD?}

In connection with the actual influence of court rulings on individual decisions made by the public administration and the development of policies of the administrative decision-making, the question asked at the beginning about whether it violates the rule of law principle remains current. The answer to that question will be negative. The analysis of decision-making processes in the public sphere from the perspective of the decision-making perspective influences the catalogue of potential sources of the law that public administration agencies will reach for. From that perspective, each factor influencing the content of a legal decision (i.e. decision-based approach to sources of the law) will be considered a source of the law. This assumption refers to the "developed normative concept of sources of the law" formulated by Z. Ziembiński, who assumes that not only legal regulations but also political justifications, customs and precedents, interpretation rules, inference rules and principles of settlement of collisions between standards of a legal system have to be classified as a part of a legal system. All of them are criteria according to which standards having specific contents are classified in the system of standards in force [23: 141-146]. However, irrespectively of the adopted concept of sources of the law, one has to remember that knowledge of the contents of rulings is a component of the entirety of knowledge of the decision-maker (administration agency) who strives to make the best decision possible in the legal, economic and social circumstances. The issue of such a decision requires the consideration and weighing of all the legal and non-legal arguments, including those formulated in statements of reasons for rulings issued by courts controlling public administration agencies.

It is also worth to note that reaching for and using arguments expressed in prior court rulings not only fails to violate the basic principles of the rule of law but can even promote the preservation of coherence of the legal order and, from the perspective of the future addressee of a decision, it contributes to the more comprehensive realisation of the principle of citizens' trust in the authorities as well as the certainty and predictability of the law and its application. Additionally, it is not possible in a state under the rule of law to make a decision authoritatively modelling rights and obligations of subjects of the law with no due legal basis in the form of (competence, procedural and material) standards embedded in sources of the law accepted in a legal system or to make a decision non-compliant with such standards or circumventing them.

As courts actually participate (irrespectively of the legal binding of the contents of a ruling) in the decision-making process in the public sphere, it is worth to think about arguments in favour and against the admission and recognition of such a possibility in a state under the rule of law.

The first and also probably the strongest argument against the participation of judges in the public management process consists of the lack of their democratic legitimacy. In principle, judges are not elected by the society and, as such, should not influence decisions (their contents) made in the public sphere. In other words, the court does not meet the democratic expectation of being "public" and has 
no "democratic credentials". A similar problem was observed with organisations and entities with no democratic legitimacy that participate in the decision-making process in the public sphere, with regard to which E. Erman and A. Uhlin ask whether global governance arrangements in which the participating actors themselves are not democratically constituted could be democratically legitimate. ${ }^{2}$ In this context, F. Vibert makes an interesting point that the separation of powers makes an important distinction between what makes a branch legitimate and what makes it accountable. Legitimacy and accountability are closely related concepts but they are not the same. Legitimacy asks how powers are justified. Accountability focuses on how powers are exercised. In democracies, those who hold power must be able both to justify their powers and also to be held to account for the way in which they exercise them. 'Accountability' is a term that is often used very broadly and in the most abstract of ways [20: 169]. At the same time, Peruzzotti [13: 158] says that, concerning non-elected organisations, it would be erroneous to consider that they do not play a legitimate role in the practice of democratic representation or that they have to become 'representative' to gain legitimacy. In principle, there are no grounds to state that above-mentioned arguments could be out-of-date to any degree with regard to the judiciary.

Another argument one can mention against the recognition of the possibility of judges influencing public decisions consists of the danger to violate the principle of the separation of powers by disturbing the balance between them. In this respect, I fully share the opinion expressed by S. Jansen who indicates that the idea of the mutual influence of the executive and the judiciary is frequently misunderstood. It is the lack of an effective possibility for a court to enter the substance of administrative decisions and, because of that, the impossibility to guarantee an effective protection of an individual from potential authoritative ambitions of public agencies that disturbs that balance. In his opinion, a more intense participation of the court in the final settlement of a case is necessary to retain the balance [9: 41-42]. From that perspective, the argument should be reversed: the court's participation in the (substantive-direct or indirect) settlement of administrative cases can play a fundamental role in the protection of an individual from an illegal action of an administration agency [11: 149-150]. that, while being responsible for its actions both organisationally and politically, can be more willing to "sacrifice" the legality of decisions for the benefit of other values and, in this manner, to violate human rights and freedoms.

Another argument worth mentioning is that judges lack necessary knowledge to evaluate administrative decisions as regards their compliance with criteria other than legality only [21: 392-393], e.g. purposefulness and efficiency, and also to determine facts of the case that are frequently strongly related to the specificity of an area of social relations within which the public administration agency executes its objectives. This argument gains more importance in those cases where the public authority operates within the limits of the legally determined freedom of decision, i.e. administrative discretion that allows it to choose the settlement that, according to the

\footnotetext{
${ }^{2}$ The same question regarding "transnational actors" is asked by Erman and Uhlin [3: 4].
} 
agency, is optimal in the circumstances from among the legally permitted variants of settlements. One can agree with such a general argument but it is not fully sustainable if we consider it in more detail. It is obvious that the court has no knowledge similar to knowledge available to the public administration agency whose objective is to manage a certain part of the reality. However, the court can, e.g. assess the purposefulness of a decision by referring it to standards and principles of the law. It does not assess the rationale of the settlement as such but rather the rationale of the issue of a decision from the perspective of the legal order as the agency's activity has to be not only compliant with the literal formulation of a legal standard (regulation) but also with the purpose for which that regulation was established [8: 52] or the purpose (objective) for the realisation of which the agency was established. ${ }^{3}$ As for decisions made within the limits of the administrative discretion, it is worth noting that court rulings actually become one of the criteria of the selection of consequences within limits determined by the law [17: 256-267]. In this context, one has to agree with the statement that the court should not enter the area of the administrative discretion too deeply (see [1:129-132]).

If we look at the phenomenon of the court's interference with decisions made in the public sphere we shall see a positive outcome (as mentioned above) in the form of a more effective protection of individual rights from an authoritarian, illegal action of public authorities. One of the downsides of the cassation model of the judicial control over the administration (i.e. the model in which the court is devoid of the legal possibilities to interfere with the contents of decisions) mentioned, among others, by Kmieciak [10: 109], is the lack of proper mechanisms (mainly sanctions) that can be applied if the agency ignores opinions expressed in the court settlement and either makes no settlement at all or reissues a decision identical with the one annulled by the court. Such a situation is called the "yo-yo effect" in the European administrative law science. This argument can be fully applied to the presented problem of the effectiveness of the judicial influence on the administration (irrespectively of the detailed competencies of the court), especially in the context of individual administrative decisions. The lack of possibility for a court to influence the settlement made by a public agency can be perceived as unjust from an individual perspective if the court considers the contested decision defective. From the perspective of expectations of participants in the procedure formulated with regard to the judiciary including administrative courts, the final effect is most important. It is the final settlement and its implications, both legal and factual, which have the greatest impact on the overall evaluation of the implementation of justice [19: 351].

It is also worth mentioning that, in addition to its preventive nature, the influence of courts on decisions made by the public administration in the public sphere (irrespectively of the type of influence) also has a formative function. Public administration is subject to the same learning processes as any other organisation $[15,16: 72-77]$. Therefore, when analysing the above-mentioned argument regarding the lack of necessary knowledge among judges when it comes to the possibility

\footnotetext{
${ }^{3}$ For example, article 3.2 of the Lithuanian act on administrative proceedings-Lietuvos Respublikos administracinių bylų teisenos įstatymas 1999m. sausio 14 d. No. VIII-1029.
} 
to substantively enter the essence of an administrative decision, the argument can be reversed by suggesting that public administration agencies (officials and acting individuals) have no such specialist legal knowledge as judges (in principle). However, such knowledge is necessary for their decisions to be defined as optimised. Additionally, such knowledge has to be continuously expanded due to the dynamism of legal and socio-economic changes. From that perspective, arguments and assessments formulated in court rulings supply public agencies with knowledge that is necessary and also objectivised, regarding the contents of legal standards and the axiology of the legal order.

\section{Conclusions}

The above-mentioned deliberations demonstrate that administrative courts influence (DO) the development of individual decisions made by public agencies and, from a wider perspective, the development of decision lines in the administration, i.e. administrative policies understood as consistent practices in specific types of cases. That influence is real (factual) and independent from detailed competencies of the court (the power of substantive settlement or only a cassation settlement). Additionally, such influence is not only permitted but also desirable in the rule of law. However, it seems necessary to distinguish (legal and/or factual) possibilities (MAY) of the judicial influence on administrative decisions in the micro- (an individual decision) and the macro- scale (decision-making policy in the public sphere) from the necessity (SHOULD) or even obligation (MUST) to interfere.

Such interference should be particularly strong in three situations: (1) if necessary in order to guarantee the protection of individual rights or (2) when required in circumstances related to an attempt at a consistent circumvention of the law by the public administration in order to attain goals defined by the prevailing political power, i.e. to guarantee the protection of the legal order, or (3) if required due to the dynamics of social changes (e.g. a deep social change related to a change of the political regime of the state that occurred in "post-communist" states) with changes of legal standards being the basis for all activities of the administration and a starting point of the legality assessment of the legality of its actions lagging behind such changes.

In principle, such interference should be prudent and rational though. ${ }^{4}$ In particular, courts should be very careful when approaching all decisions issued within the limits of the discretionary power available to the administration. Such decisions should be subjected to particularly in-depth analyses but any potential interference with their contents should only take place in one of the three cases indicated above.

\footnotetext{
${ }^{4}$ [2: 270]. These boundaries are very liquid and, at the same time, the analysis of the ruling practice of courts verifying administrative cases in those countries where they have cassation powers indicates that such powers are used in a rather prudent and careful manner; for example, the Finnish Supreme Administrative Court (Finnish report for the IASAJ Congress in Sydney, March 2010, https://www.aihja.org/ images/users/1/files/finland.en.0.pdf, pp. 10-11, access: 17.03.2018.).
} 
An independent court should have an opportunity to evaluate whether a potential need exists to make a settlement encroaching on or essentially replacing an administrative decision [6: 133-137].

Not only the recognition of the judicial interference with administrative decisions as a certain factual phenomenon but also as a phenomenon that is desirable from the point of view of the axiology of the state under the rule of law are justified. Such a state is about an effective protection of its basic values including individual rights and freedoms. The effectiveness of judicial influence on decisions made by the public administration promotes not only a more comprehensive realisation of the principle of the balance of powers but also a more effective protection of an individual and the legal order. Additionally, the discourse taking place between courts and agencies in connection with it makes it possible for the latter to make more optimal decisions being the product of legal and non-legal arguments in all those "areas" of decision processes where they enjoy powers of discretion. However, the independence of the court is the sine qua non condition.

Open Access This article is distributed under the terms of the Creative Commons Attribution 4.0 International License (http://creativecommons.org/licenses/by/4.0/), which permits unrestricted use, distribution, and reproduction in any medium, provided you give appropriate credit to the original author(s) and the source, provide a link to the Creative Commons license, and indicate if changes were made.

\section{References}

1. Ackerman, Bruce. 2011. Good-bye, Montesquieu. In Comparative administrative law, ed. Susan Rose-Ackerman, Peter L. Lindseth, and Blake Emerson. Cheltenham: Edward Elgar Publishing.

2. Asimow, Michael, and Jeffrey S. Lubbers. 2010. The merits of 'Merits' review. A comparative look at the Australian Administrative Appeals Tribunal. Windsor Yearbook of Access to Justice 28: 270.

3. Erman, Eva, and Anders Uhlin. 2010. Democratic credentials of transnational actors: An introduction. In Legitimacy beyond the state? Re-examining the democratic credentials of transnational actors, ed. Eva Erman and Anders Uhlin. New York: Palgrave Macmillan.

4. Grant, James A. 2017. Reason and authority an administrative law. The Cambridge Law Journal 76(3): 507-536

5. Harlow, Carol, and Richard Rowlings. 2009. Law and administration. Cambridge: Cambridge University Press.

6. Holoubek, Michael. 2013. Kognitionbefugnis, Beschwerdelegitimation und Beschwerdegegenstand der Verwaltungsgerichte, In Die Verwaltungsgerichtsbarkeit erster Instanz, ed. Michael Holoubek and M. Lang, Wien. C.F. Müller.

7. Jacobs, Edward. 2011. Tribunal practice and procedure. London: Legal Action Group.

8. Jakimowicz, Wojciech. 2010. Zewnętrzne granice uznania administracyjnego. In Państwo i Prawo.

9. Jansen, Sander. 2005. Towards an adjustment of the Trias Politica. In Judicial lawmaking and administrative law, ed. Frits Stroink and Eveline van der Linden, 37-55. Intersentia: Antwerpen-Oxford.

10. Kmieciak, Zbigniew. 2010. Postępowanie administracyjne $i$ sqdowoadministracyjne a prawo europejskie. Warszawa: Wolters Kluwer.

11. Kmieciak, Zbigniew. 2013. The efficiency of administrative courts (in the light of European and Polish experiences). Comparative Law Review 15: 149-150.

12. Korybski, Andrzej, and Leszek Leszczyński. 2013. Decision making approach in a study of the enactment and application of law: A pragmatic context of legal theory. In Legal theory and philosophy of law: Toward contemporary challenges, ed. Andrzej Bator and Zbigniew Pulka, 156-181. Warsaw: Scholar Publishing House. 
13. Peruzzotti, Enrique. 2010. Democratic credentials or bridging mechanisms? Constituents, representatives, and the dual politics of democratic representation. In Legitimacy beyond the state? Reexamining the democratic credentials of transnational actors, ed. Eva Erman and Anders Uhlin, 153-172. Houndmills: Palgrave.

14. Popescu, Doina. 2013. Judicial control of public administration in European Union countries. AGORA International Journal of Juridical Sciences 1: 143-149.

15. Senge, Peter Michael. 1990. The fifth discipline. New York: Doubleday Currency.

16. Stefaniuk, Marek. 2009. Działanie administracji publicznej w ujęciu nauk administracyjnych. Lublin: Wydawnictwo UMCS.

17. Szot, Adam. 2016. Swoboda decyzyjna w stosowaniu prawa przez administracje publiczna. Lublin Wydawnictwo Episteme.

18. Szot, Adam. 2018. Judicial review of administrative discretion-Court as a "Guard" and "Navigator”. Frankfurt am Main: Peter Lang.

19. Szuster, Sergiusz. 2010. Koncepcja merytorycznych kompetencji orzeczniczych. Kraków: Jagiellonian University.

20. Vibert, Frank. 2007. The rise of the unelected democracy and the new separation of powers. Cambridge: Cambridge University Press.

21. Walter, Robert. 1976. Kassatorische oder reformatorische Entscheidung? In Die Entwicklung der österreichischen Verwaltungsgerichtsbarkeit, Festschrift zum 100 jährigen Bestehen des österreichischen Verwaltungsgerichtshofes, ed. Friedrich Lehne, Edwin Loebenstein, and Bruno Schimetschek. Wien: New York.

22. Wilberg, Hanna, and Mark Elliott. 2015. The scope and intensity of substantive review: Traversing Taggart's rainbow. Oxford: Hart Publishing.

23. Wronkowska, Sławomira, and Zygmunt Ziembiński. 1997. Zarys teorii prawa. Poznań: Ars Boni et Aequi.

Publisher's Note Springer Nature remains neutral with regard to jurisdictional claims in published maps and institutional affiliations. 